\title{
Morphological, histological and ultrastructural studies on the testes of Liza carinata from the Suez Bay in correlation with its reproductive cycle
}

\author{
Fawzia A. A. Abd El-Rahman', Hamza A. El-Shabaka' ${ }^{1}$, William Rizkalla ${ }^{1}$, \\ Azza A. El-Ganainy ${ }^{2}$, and Mazaya E. Abo-Mosallam ${ }^{1}$ \\ ${ }^{1}$ Department of Zoology, Faculty of Science, Ain Shams University, Abbassia Sq, 11566, Cairo, Egypt. \\ ${ }^{2}$ National Institute of Oceanography and Fisheries, Suez branch, 183, Suez, Egypt.
}

\begin{abstract}
Despite that Liza carinata (Mugiliformes: Mugilidae) is economically important fish of the Red Sea, little information is known about its testicular cycle. Moreover, a good understanding of the reproductive parameters of a fish such as the gonadal development, sexual maturation, gonado-somatic index and spawning season, is of paramount importance for the fisheries management. So, the present study is aimed to gain more information about the morphology, histology and ultrastructure characteristics of male $L$. carinata during its reproductive cycle.

According to the seasonal variations in the gonado-somatic index of males $L$. carinata, the year can be divided into three seasons, namely: the pre-spawning season (from early June to late August), the spawning season (from early September to Late December) and the post-spawning season (from early January to late May). The average values of gonado-somatic index were small in the pre-spawning season and then they increased sharply to reach the highest value in the spawning season. The values of GSI decreased gradually to reach the smallest value in the post-spawning season.

Histologically, the testis of $L$. carinata is formed of a large number of highly convoluted seminiferous lobules. Each seminiferous lobule is divided into numerous isogenic cysts which contain different stages of the spermatogenic cells that enclosed by the Sertoli cells. Six stages of the spermatogenic cells can be identified in the seminiferous lobules during the different seasons, namely: the spermatogonia A and B, primary and secondary spermatocytes, spermatids and spermatozoa. In addition, the ultrastructural examination revealed that the spermatids are differentiated into three different stages, namely: the early, middle and late spermatids. The spermatozoa have similar structure to those of fish that breed through external fertilization, thus classifying them as uniflagellate anacrosomal aquasperm.
\end{abstract}

Keywords: Liza carinata, gonado-somatic index, cystic testes, unrestricted spermatogenesis, aquasperm.

\section{INTRODUCTION}

Liza carinata (Valenciennes, 1836) is a small to a moderate-sized mullet that has great nutritional and commercial values. This fish species spreads extensively from Japan, Korea, China, and Malay Archipelago to India and Red Sea (Yoshino and Seno, 1984). Teleostean fishes belonging to family Mugilidae are one of the most common species in the Red Sea. Moreover, the family Mugilidae includes 17 genera and 72 species in the world (Harrison and Senou, 1999 and Nelson, 2006). The mullets have supreme economic importance because they represent a productive source of animal protein for human consumption.

Grier et al. (1980b), Grier (1981) and Parenti and Grier (2004) stated that the structure of the testes in the teleost fishes is generally divided into two types: the unrestricted and restricted spermatogonial types, according to the distribution of the 
spermatogonia. Moreover, the previous authors stated that the spermatogonia of the testes of the Salmoniformes, Perciformes and Cypriniformes fishes are distributed along the entire length of the testicular tubules and this represents the unrestricted spermatogonial type. However, the spermatogonia of the testes of the Atheriniformes fishes are restricted to the distal end of the tubules and this represents the restricted spermatogonial type.

Bruslé (1981) and Gwo and Gwo (1993) stated that the spermiogenesis in Liza aurata and Acanthopagrus schlegeli, respectively involves conspicuous modifications of the spermatids such as structural changes (the nuclear chromatin becomes more homogeneous and forms coarse dense granules and formation of the flagellum) and intracellular movements (the centrosome-nucleus complex formation and cytoplasm depletion).

Ramadan et al. (1987a and b) stated that, according to the morphological changes, the maturity stages of the testes of Sparus aurata are divided into five stages, namely: the immature, maturation, pre-spawning, spawning and resting stages.

In general, the process of spermatogenesis of teleosts is quite similar where the germ cells develop inside the cysts and at the end of the process, the cysts open and spermatozoa are released into the lobular lumina. This type is called cystic spermatogenesis because the process completes inside cysts as in South American catfishes (Loir et al., 1989) and in Xenentodon cancila (Chakrabarti and Banerjee, 2015). However, the semicystic spermatogenesis does not follow this pattern and in which the spermatids released into the lobular lumina where sperm maturation occurs without any physical connection with the Sertoli cells. This semicystic spermatogenesis was first described by Mattei et al. (1993) in the genus Ophidion and has been described in a few teleosts species such as Scorpaena notata (Munoz et al., 2002) and Scorpaena porcus and Scorpaena scrofa (Sabat et al. 2009).

Knowledge of the gonadal cycle and its functional mechanisms in fishes has a great importance in the successful management of fisheries. Therefore, the present work is aimed to describe the morphological, histological and ultrastructural changes of testes of male Liza carinata during its reproductive cycle.

\section{MATERIALS AND METHODS}

100 adult specimens of male Liza carinata, ranging from $12-18 \mathrm{~cm}$ as a total length and 13-72 gm in body weight, were collected from the Suez Bay, Red Sea which is about 120 kilometers east of Cairo. The specimens were collected during two years (from January 2009 to January 2011) cover the reproductive cycle of the fish. The capture of specimens was performed twice per season. Fish samples were obtained alive from the commercial fishermen operating in the region using trammel nets. The specimens were than weighted and dissected to expose testes for the further studies.

\section{1- The gonado-somatic index (GSI):-}

To evaluate the state of maturity of the testes, the gonado-somatic index (GSI) of male $L$. carinata, from the Suez Bay, was computed as percentage weight of testes to that of the total body weight for each fish using the following equation:

$$
\text { GSI }=\frac{\text { Weight of testes }}{\text { Total body weight of fish }} \times 100 \text {. }
$$

\section{2- The morphological description of the testes:-}

Male fishes were dissected and the testes were exposed and photographed by the Sony digital Camera. The testes were removed out, blotted by a filter paper and 
weighed. The length of each testis was recorded for each specimen. Then, the testes were grossly examined and were placed in the proper stage of maturity, according to the size, shape and colour.

\section{3- The histological studies:-}

The dissected testes of each fish were cut into small parts in order to provide a good penetration of the fixative. These parts were fixed immediately in a freshly prepared aqueous Bouin's fluid for 24 hours. Then the materials were dehydrated through an up graded series of ethyl alcohol and cleared in terpineol. Serial transverse sections of the testes were cut at 5-7 $\mu \mathrm{m}$ in thickness and stained with Harris' hematoxylin and eosin as a counterstain according to Humason (1979). After staining, the sections were carefully examined and photomicrographs were made. Measurements were taken by using the research microscope with a measuring calibrated eye piece micrometer. The diameters of each spermatogenic stage and its nucleus were measured for at least 30 randomly chosen fields.

\section{4- The ultrastructural studies:}

Small pieces of the testis were fixed in cold 3\% glutaraldehyde solution in phosphate buffer ( $\mathrm{pH} \mathrm{7.4)}$ ) for 2 hours at $4^{\circ} \mathrm{C}$. The materials were then post-fixed in $2 \%$ osmium tetroxide $\left(\mathrm{OsO}_{4}\right)$ for one hour in a dark place at $4^{\circ} \mathrm{C}$. After that, the materials were dehydrated in an ascending ethanol series ten minutes each, at $4^{\circ} \mathrm{C}$. The materials were then cleared in propylene oxide and were embedded in epoxy resin at $60^{\circ} \mathrm{C}$. Semithin sections ( $1 \mu \mathrm{m}$ thick) were cut with the RMC-MT7 ultramicrotome and stained with toluidine blue. The semithin sections were then examined to select the suitable areas for ultrathin sectioning. Ultrathin sections $\left(600 \mathrm{~A}^{\circ}\right.$ thick) were cut and stained with uranyl acetate and lead citrate according to Reynolds (1963). Finally, the sections were then examined with JOEL 1200 EXII at the Electron Microscope Unit, the Central Laboratory, Faculty of Science, Ain Shams University.

\section{RESULTS AND DISCUSSION}

\section{The gonado-somatic index:-}

In fisheries studies, the spawning season is an important factor for regulating fisheries (King, 2007). In the present study, the average values of gonado-somatic index were small in the summer which is considered as the pre-spawning season and then they increased sharply to reach the highest value in the autumn and early winter (the spawning season). The values of GSI decreased gradually in late winter and then it reached the smallest value in the spring (the post-spawning season). Similar results were observed by Aguirre and Gallardo-Cabello (2004) who stated that Mugil cephalus from the coastal lagoon in the Gulf of Mexico is observed to spawn in autumn and winter. The seasonal variations of the gonado-somatic index profile of male $L$. carinata appears more or less similar to those found by Salem and Mohammed (1982) who showed that the maximum value of the gonado-somatic index of Mugil seheli in Lake Timsah occurs in December for both sexes. Moreover, Hotos et al., (2000) stated that the maximum value of the gonado-somatic index of L. aurata in the Klisova lagoon occurs from August to November and its spawning season extends from the end of summer to the end of autumn. 
Table (1): The seasonal variations in gonado-somatic index (GSI) of males L. carinata from the Suez Bay.

\begin{tabular}{|c|c|c|}
\hline Seasons & GSI & S.D. \\
\hline Summer & 0.543 & 0.213 \\
Autumn & 4.771 & 0.346 \\
Winter & 3.17 & 0.338 \\
Spring & 0.27 & 0.643 \\
\hline
\end{tabular}

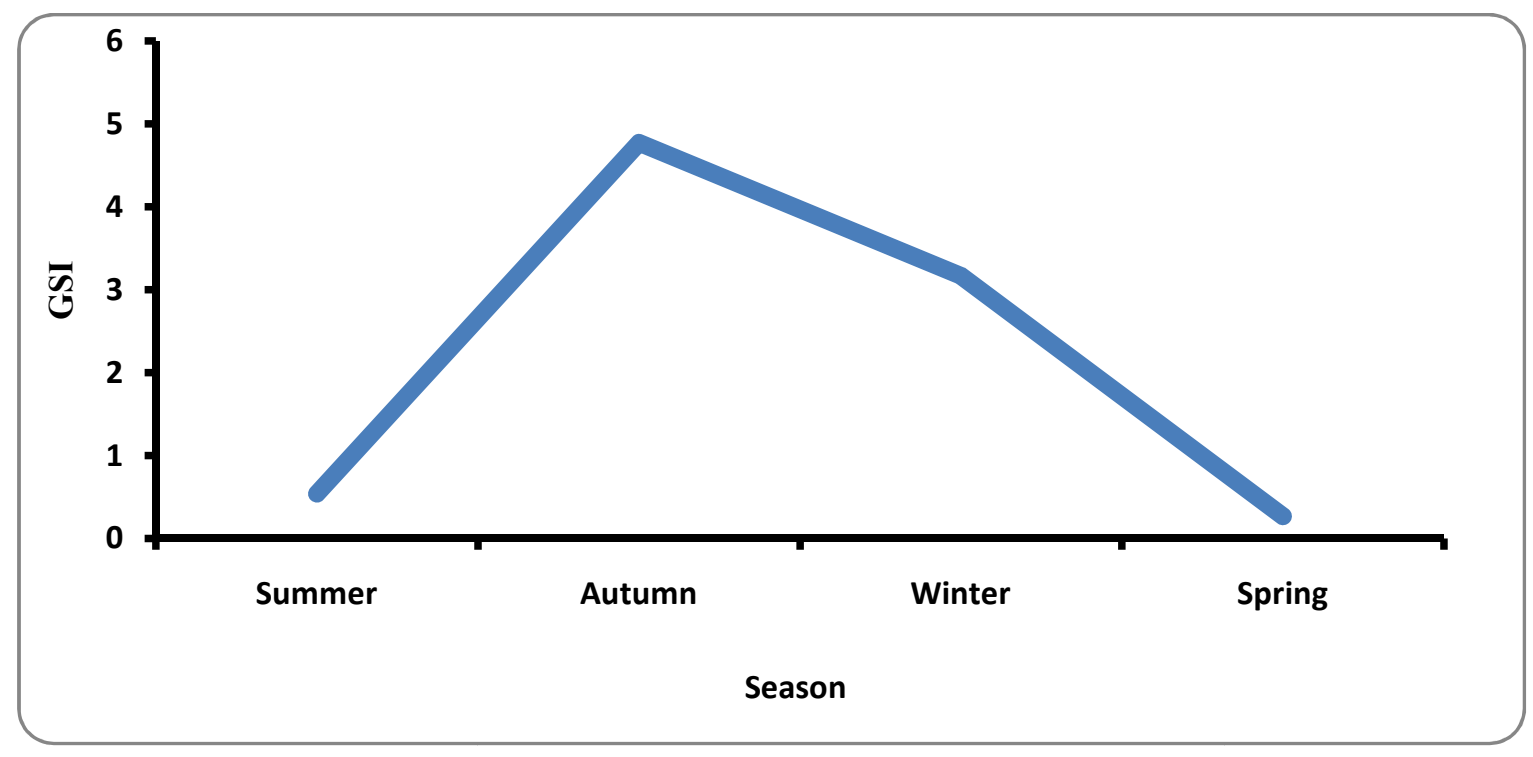

Fig. 1: The seasonal variations in gonado-somatic index (GSI) of males $\boldsymbol{L}$. carinata from the Suze Bay.

\section{A- The morphological studies: -}

The testes of $L$. carinata are paired, elongated and flattened structures which appear more or less equal in size. The testes of $L$. carinata exhibit remarkable variations in size, shape, and colour according to the maturity stage of the fish during the different seasons of the year. The maturity stages of the testes of L carinata can be divided seasonally into three stages, namely: the pre-spawning (from early June to late August), the spawning (from early September to Late December) and the post-spawning (from early January to late May), (Figs. 2A, B and C).

During the pre-spawning stage, the testes are stout, cylindrical in shape, with smooth texture, pinkish white in colour and show a remarkable increase in size. They are measuring about $4.9 \mathrm{~cm}$ as a mean length and occupy more than half of the length of the abdominal cavity (Fig. 2A). Moreover, the testes in the spawning stage are voluminous, turgid, highly vascularized and white in colour. They attain their maximum size; they are measuring about $6 \mathrm{~cm}$ as a mean length and fill the majority of the abdominal cavity (Fig. 2B). In addition, during the post-spawning stage the testes appear flaccid, reduced in size and white in colour. Moreover, the testes occupy about half of the length of the abdominal cavity with an average length equals about $4 \mathrm{~cm}$ (Fig. 2C). Similar variations were postulated by Chakrabarti and Bose (2014), in Liza parsia, and Chakrabarti and Banerjee (2015), in Xenentodon cancila, who also suggested that the increase in the testes size during the spawning season is due to the active proliferation of the spermatogenic cells. 
B- The histological and ultrastructure studies:-

The testis of L. carinata is formed of a large number of highly convoluted seminiferous lobules and is covered by a thin connective tissue capsule, the tunica albuginea (Figs. 3 and 4). The seminiferous lobules are separated by the interlobular connective tissue septa that contain the interstitial cells. The interstitial cells are cuboidal cells with an eosinophilic cytoplasm and oval nuclei. The spermatogenic cells of $L$. carinata are found in cysts and are usually surrounded by the Sertoli cells which are more or less flattened in shape and have oval nuclei (Fig. 5). Testis organization into two compartments, namely: the germinal and interstitial compartments were also reported by Grier et al. (1980a), in Poecilia latipinna, Abou Shabana (2012), in Diplodus cervinus cervinus, Vergilio et al. (2013), in Gymnotus carapo, and Zupa et al. (2013), in Thunnus thynnus.

Each seminiferous lobule of $L$. carinata possesses numerous isogenic cysts that contain a single type of the different spermatogenic stages (Fig. 6). Similar results were obtained in Otolithes ruber (Dadzie and Abou-Seedo, 2004) and in Oligosarcus hepsetus (Santos et al., 2006). The spermatogenesis of L. carinata, as the majority of teleosts, is of the cystic type, which is occurred inside the cysts and is characterized by the release of mature spermatozoa into the lobular lumina (Koulish et al., 2002 and Schulz et al., 2010). In addition, Schulz et al. (2010) stated that the Sertoli cells of the cystic spermatogenesis might be more efficient in supporting the germ cell development because they concentrating specific growth factors required for each developmental phase and consequently providing high spermatogenic yield.

Six stages of the spermatogenic cells can be identified in the seminiferous lobules of $L$. carinata during the different seasons, namely: the spermatogonia A and B, primary and secondary spermatocytes, spermatids and spermatozoa. These observations were similar to those found by Ramadan et al. (1987a and b) in Sparus aurata, Rahemo and Al-Shatter (2012) in Barbus luteus and Varicorhinus trutta and Abou Shabana (2012) in Diplodus cervinus cervinus.

In L. carinata, the spermatogonia A and B are most prominent in the testes during the post-spawning season, while the primary spermatocytes, secondary spermatocytes and spermatids are found mainly in the pre-spawning and spawning seasons. Moreover, the spermatozoa are most prominent in the pre-spawning and spawning seasons, but there are some residual spermatozoa in the seminiferous lobules in the post-spawning season (Fig. 4). Similarly, Zupa et al. (2013), in Thunnus thynnus, and Chakrabarti and Banerjee (2015), in Xenentodon cancila, stated that the germinal epithelium of the testes during the pre-spawning season consists of spermatogonia A and B, spermatocytes, spermatids and few spermatozoa which are sometimes observed in the seminiferous lobules. In addition, the germinal epithelium, during the spawning season, is formed mainly of spermatogonia and spermatozoa that fill the lumen of the seminiferous lobules, while during the post-spawning season the germinal epithelium is mainly built up of spermatogonia and residual spermatozoa in the lumen.

\section{1- The spermatogonia A:-}

In $L$. carinata, the spermatogonia A are the largest cell type of the spermatogenic cells of the testes; their mean diameter is about $11 \mu \mathrm{m}$. The spermatogonia A usually occur solitary, but some of them are found in small groups of two or three cells. Each spermatogonium A is spherical in shape and possesses a distinct cell membrane, faintly stained cytoplasm and a large spherical and centrally located nucleus. The nucleus mean diameter is about $6 \mu \mathrm{m}$ and has a single, spherical and centrally located nucleolus (Figs. 5 and 7 ).

Moreover, the testicular structure of L. carinata is considered to be of the unrestricted spermatogonial type, in which the spermatogonia are distributed along the entire length of the seminiferous lobules (Figs. 4 and 7). Similar observation was 
recorded by Lee et al. (2006), in Macropodus opercularis, Abou Shabana (2012), in Diplodus cervinus cervinus, and Siqueira-Silva et al. (2013), in Cichla kelberi. However, Vicentini et al. (2010) stated that the testicular structure of Phalloceros caudimaculatus is considered to be of the restricted spermatogonial type.

Ultrastructurally, the cytoplasm of the spermatogonia A of L. carinata contains few organelles which include cytoskeletal microtubules, free ribosomes and large spherical mitochondria. The most characteristic feature of the cytoplasm of this stage is the presence of electron dense masses that are seen outside the nuclear membrane and have been named the perinuclear nuages, suggesting a nucleo-cytoplasmic exchange. These perinuclear nuages are found either as free or associated with the mitochondria to form the intermitochondrial cement (Fig. 8). Such the perinuclear nuages persist throughout the spermatogenesis until the spermatid stage, but their size and number is far higher in the spermatogonia A stage. Similar results were postulated by Abascal et al. (2004) in Thunnus thynnus. Moreover, Magalhaes et al. (2011) suggested that these perinuclear nuages may be formed of RNA and proteins and may be resulted from the cytoplasmnuclear exchanges.

\section{2- The spermatogonia $B$}

The spermatogonia $\mathrm{B}$ of $L$. carinata are formed by mitotic divisions of spermatogonia A and they occur in groups of a small number. These cells are similar in shape to the spermatogonia A, but they are smaller in size. These cells are rounded in shape with little eosinophilic cytoplasm and rounded and centrally located nuclei. Each nucleus possesses a rounded nucleolus (Fig. 5). The mean diameter of the spermatogonia B is about $8 \mu \mathrm{m}$ and the mean diameter of their nuclei is about $5 \mu \mathrm{m}$. Similar observations were postulated by Abascal et al. (2004), in Thunnus thynnus, and Abou Shabana (2012), in Diplodus cervinus cervinus.

Ultrastructurally, the cytoplasmic organelles of the spermatogonia B of L. carinata are represented by the cisternae of the endoplasmic reticulum, free ribosomes and spherical mitochondria which are aggregated around the perinuclear nuages to form the intermitochondrial cement (Fig. 9). These results agree with those of Chung et al. (2010), in Pampus argenteus, and Abou Shabana (2012), in Diplodus cervinus cervinus.

\section{3- The primary spermatocytes}

The primary spermatocytes of $L$. carinata are formed by mitotic divisions of the spermatogonia B and they are found in large groups that are wrapped in cysts (Figs. 6 and 7). The primary spermatocytes are spherical in shape, with a poorly defined cell membrane, and smaller in size (measuring about $5 \mu \mathrm{m}$ in the mean diameter) as compared with the spermatogonia B. Each primary spermatocyte possesses a scanty and faintly stained cytoplasm and a small spherical nucleus with a mean diameter of about $3.8 \mu \mathrm{m}$. The nuclei of the primary spermatocytes contain chromatin patches, hence the nucleoli are not clearly defined (Fig. 10). These results were similar to those of other teleost species such as Solea senegalensis (Garcia-Lopez et al., 2005) and Pampus argenteus (Lone et al., 2008).

Ultrastructurally, the nucleus of the primary spermatocyte of $L$. carinata has numerous chromatin patches that are found either near the nuclear membrane or scattered in the nucleoplasm (Fig. 11). These chromatin patches increase with the development of the spermatogenic cell to fill the entire nucleus. Moreover, the cytoplasm of the primary spermatocyte of L. carinata contains the endoplasmic reticulum, free ribosomes, mitochondria and the intermitochondrial cement (Fig. 12). These observations were in accordance with those reported by Abou Shabana (2012).

\section{4- The secondary spermatocytes}

In L carinata, the secondary spermatocytes are formed by an active first maturation division (meiosis I) of the primary spermatocytes and are found in large numbers inside 
cysts (Figs. 6 and 7). They are smaller in size as compared with the primary spermatocytes and their mean diameter is about $4 \mu \mathrm{m}$. Each secondary spermatocyte is spherical in shape and contains a spherical and basophilic nucleus with a smooth outline. The mean diameter of these nuclei is about $3 \mu \mathrm{m}$. The cytoplasm of each cell is represented by a thin eosinophilic rim around the nucleus. The nucleoli and cell membrane are not clearly defined (Fig. 10). These observations were in accordance with those of Vergilio et al. (2013), in Gymnotus carapo, who also stated that during the spermatogenic process, there is reduction in nuclear size and increase in the nuclear condensation.

Ultrastructurally, the secondary spermatocyte of L. carinata possesses a spherical, centrally located nucleus with condensed and randomly distributed chromatin patches. The nucleoli of the secondary spermatocytes are not visible (Fig. 13). In addition, the cytoplasm of the secondary spermatocyte is reduced and contains cisternae of endoplasmic reticulum, free ribosomes, few intermitochondrial cement and mitochondria (Fig. 14). These results agree with those of Shahin (2006), in Alestes dentex.

\section{5- The spermatids}

The spermatids of $L$. carinata are formed by the second maturation division (meiosis II) of the secondary spermatocytes. The spermatids are very small in size, spherical in shape and are found in a large number that enclosed in cysts. The nucleus of the spermatid is rounded and deeply basophilic, while its cytoplasm is scanty and faintly stained (Figs. 6 and 15). The spermatid mean diameter is about $2.3 \mu \mathrm{m}$, while the nucleus mean diameter is about $1.7 \mu \mathrm{m}$. The current results were in agreement with those recorded in Brycon cephalus (Romagosa et al., 1999).

The spermatids of $L$. carinata are transformed into the spermatozoa by the process of the spermiogenesis which comprises the nuclear condensation, flagellum formation and cytoplasmic reduction. According to the progress of the spermiogenesis, the spermatids are differentiated ultrastructurally into three different stages, namely: the early, middle and late spermatid stages.

The early spermatids of $L$. carinata are connected with each other by the cytoplasmic bridges. Each spermatid is spherical in shape with a large spherical and electron dense nucleus. The cytoplasmic organelles are few and are represented by the centrioles, few endoplasmic reticulum and mitochondria (Fig. 16). Similar observations were recorded by Sprando and Russell (1988), in Lepomis macrochirus.

The middle spermatids of $L$. carinata are more or less oval in shape with rounded nuclei (Figs. 17 and 18). Concomitant with the spermatid maturation, the nucleus invaginates to form the nuclear fossa and it becomes kidney shaped (Fig. 18). The nucleus of this stage moves to an eccentric position, while the cytoplasm, with the cytoplasmic organelles, migrates to the opposite pole of the cell. The nucleus contains numerous electron dense chromatin patches. The cytoplasm of this stage possesses mitochondria and centrioles (Figs. 17 and 18). There are proximal and distal centrioles which are arranged at right angle to each other (Fig. 18). The centrioles gradually migrate from a position near the cell membrane to the nuclear fossa of the nucleus, (Figs. 18 and 19). The middle spermatids begin to discard excess cytoplasm by exocytosis, leaving the so-called residual bodies of various sizes and shapes (Fig. 19). Similarly, Zaki et al. (2005) reported the same way of cytoplasm reduction of spermatids of Boops boops.

The late spermatid possesses a kidney-shaped nucleus with electron dense chromatin patches. The cytoplasm is scarce and contains mitochondria which aggregate around the base of the short primordial flagellum (Fig. 20). Similar observations were recorded by Zaki et al. (2005), in Boops boops. 


\section{6- The spermatozoa}

The spermatozoon of L. carinata consists of a small basophilic head and a thin, long and eosinophilic tail (Figs. 6 and 7). The nucleus of the spermatozoon is located in the head and is nearly spherical in shape with a mean diameter of about $1.3 \mu \mathrm{m}$ (Fig. 15). The spermatozoa aggregate first as a parachute shaped groups in the seminiferous lobules (Figs. 6 and 7), then they fill all the seminiferous lobule and form the sperm clouds. Finally, they migrate to the spermatic duct (Fig. 21). Similar results were reported in Liza ramada (El-Halfawy et al., 2007).

Ultrastructurally, the mature spermatozoon of L. carinata is of aquasperm type which is divided into three regions, namely: the head, a short middle piece and a relatively long flagellum or tail regions. The head is rounded and contains the kidney shaped nucleus which is densely packed with chromatin patches. The nucleus is surrounded by a narrow rim of cytoplasm without organelles (Fig. 22). Each spermatozoon is characterized by the absence of the acrosome, as in the majority of teleost fish [Jun et al. (2006), in Kareius bicoloratus; Chung et al. (2010), in Pampus argenteus, and Abou Shabana (2012), in Diplodus cervinus cervinus]. The absence of acrosomes in spermatozoa is justified by the presence of a structure called micropyle in the oocytes of some teleost species which helps the penetration of the spermatozoa (Ricardo et al., 1996).

The middle piece of the mature spermatozoon of $L$. carinata is a short part connecting the head with the flagellum. The middle piece encircles the base of flagellum and contains few spherical or ovoid mitochondria (Fig. 22). Similarly, Zaki et al. (2005), in Boops boops, (Maricchiolo et al., 2007), in Sparus aurata, and Abou Shabana (2012), in Diplodus cervinus cervinus, postulated that the short or reduced spermatozoal middle piece is a common feature in teleosts with external fertilization. However, in the internally fertilized teleosts, the spermatozoon is of the introsperm type that is characterized by an elongated cone shaped head, a long middle piece with numerous mitochondria and long flagellum as in Scoloplax distolothrix (Spadella et al., 2006). In addition, the duration of sperm motility may depend to some extent on the number of mitochondria stored in the middle piece due to the mitochondrial respiration is the main energy source for sperm motility (Baccetti et al., 1984 and Lahnsteiner and Patzner, 1995).

In the mature spermatozoon of $L$. carinata, the flagellum consists of nine peripheral microtubule doublets surrounding a central pair of microtubules $(9+2$ pattern). The long flagellum has two wing-like projections, the flagellar wings or sidefins (Fig. 23). These observations were in accordance with those found by Medina et al. (2000), in Solea senegalensis, and Beirao et al. (2015), in Mallotus villosus and Osmerus mordax. Moreover, Maricchiolo et al. (2004), who observed unpaired sidefin in the spermatozoon of Pagellus erythrinus, stated that the function of these sidefins may be related to the swimming behavior of the spermatozoon to achieve fertilization. Conversely, Maricchiolo et al. (2010) stated that the flagellum of Pagellus bogaraveo has no sidefins.

\section{CONCLUSION}

The present study describes the morphological, histological and ultrastructural characters of testes of male $\boldsymbol{L}$. carinata and clarifies the general reproductive pattern to help in this species aquaculture. Moreover, the present investigation shows that the spawning season of $\boldsymbol{L}$. carinata extends from early September to late December. 


\section{REFERENCES}

Abascal, F. J.; Megina, C. and Medina, A. (2004). Testicular development in migrant and spawning bluefin tuna (Thunnus thynnus L.) from the eastern Atlantic and Mediterranean. Fish. Bull., 102: 407-417.

Abou Shabana, N. M. (2012). Ultrastructural study of spermatogenic stages in the protandrous sparid fish, Diplodus cervinus cervinus (Lowe, 1838) from the south eastern Mediterranean coast. Afr. J. Biotechnol., 11(28): 7270-7285.

Aguirre, A. L. I. and Gallardo-Cabello, M. (2004). Reproduction of Mugil cephalus and M. Curema (Pisces: Mugilidae) from a coastal lagoon in the Gulf of Mexico. Bull. Mar. Sci., 75(1): 37-49.

Baccetti, B.; Burrini, A. G.; Callaini, G.; Gilbertini, G.; Mazzini, M. and Zerunian, S. (1984). Fish germinal cells. I. Comparative spermatology of seven cyprinid species. Gamete Res., 10: 373-396.

Beirao, J.; Lewis, J. A. and Purchase, C. F. (2015). Spermatozoa ultrastructure of two osmerid fishes in the context of their family (Teleostei: Osmeriformes: Osmeridae). J. Appl. Ichthyol., 31: 28-33.

Bruslé, S. (1981). Ultrastructure of spermiogenesis in Liza aurata Risso, 1819 (Teleostei, Mugilidae). Cell Tiss. Res., 217: 415 - 424.

Chakrabarti, P. and Banerjee, A. S. (2015). Histological findings and seasonal distribution of different germ cells in the testicles of freshwater needle fish, Xenentodon cancila (Hamilton). Int. J. Fish. Aquat. Stud., 2(3): 74-80.

Chakrabarti, P. and Bose, S. (2014). Cyclical rhythms in the cytomorphology of testis of brackish water grey mullet, Liza parsia (Hamilton, 1822) inhabiting south-eastern coast of India. J. Entomol. Zool. Stud., 2 (1): 110-118.

Chung, E. Y.; Yang, Y. C.; Kang, H. W.; Choi, K. H.; Jun, J. C. and Lee, K. Y. (2010). Ultrastructure of germ cells and the functions of Leydig cells and Sertoli cells associated with spermatogenesis in Pampus argenteus (Teleostei: Perciformes: Stromateidae). J. Zool. Stud., 49(1): 39-50.

Dadzie, S. and Abou-Seedo, F. (2004). Testicular structure and spawning cycle in the silvery croaker, Otolithes ruber (Perciformes: Sciaenidae) in the Kuwaiti waters of the Arabian Gulf. J. Ichthyol. Res., 51: 263-268.

El-Halfawy, M. M. (2004). Reproductive biology of Mugil seheli (Family: Muglidae) reared in fish farm. Egypt. J. Aquat. Res., 30(B): 234-240.

El-Halfawy, M. M.; Ramadan, A. M. and Mahmoud, W. F. (2007). Reproductive biology and histological studies of the grey mullet, Liza ramada, (Risso, 1826) in Lake Timsah, Suez canal. Egypt. J. Aquat. Res., 33(1): 434-454.

Garcia-Lopez, A.; Martinez-Rodriguez, G. and Sarasquete, C. (2005). Male reproductive system in Senegalese sole, Solea senegalensis (Kaup): Anatomy, histology and histochemistry. Histol. Histopathol., 20: 1179-1189.

Grier, H. J. (1981). Cellular organization of testis and spermatogenesis in fishes. Am. Zool., 21(2): 345-357.

Grier, H. J.; Horner, J. and Mahesh, V. B. (1980a). The morphology of enclosed testicular tubules in a teleost fish, Poecilia latipinna. Trans. Am. Micros. Soc., 99(3):268-276.

Grier, H. J.; Linton, J. R.; Leatherland, J. F. and De Vlaming, V. L. (1980b). Structural evidence for two different testicular types in teleost fishes. Am. J. Anat., 159(3): 331-345.

Gwo, J. C. and Gwo, H. H. (1993). Spermatogenesis in the black porgy, Acanthopagrus schlegeli (Teleostei: Perciformes: Sparidae). Mol. Reprod. Dev., 36: 75-83. 
Harrison, I. J. and Senou, H. (1999). Order: Mugiliformes. In: "The Living Marine Resources of the Western Central Pacific". Carpenter, K. E. and Niem, V. H. (eds.). FAO species identification guide for fisheries purposes. FAO, Rome, 4(2): 2069-2083.

Hotosa, G. N.; Avramidou, D. and Ondrias, I. (2000). Reproduction biology of Liza aurata (Risso, 1810), (Pisces- Mugilidae) in the lagoon of Klisova (Messolonghi, W. Greece). Fish. Res., 47: 57-67.

Humason, G.L. (1979). Animal Tissue Techniques. $4^{\text {th }}$ edition, W.H. Freeman (ed.) San Francisco.

Jun, J. C.; Chung, E. Y. and Yang, Y. C. (2006). Ultrastructure of germ cells, cyst epithelial cells and interstitial cells during spermatogenesis of the stone flounder, Kareius bicoloratus. Kor. J. Ichthyol., 18: 311-318.

King, M. (2007). Fisheries Biology, Assessment and Management. $2^{\text {nd }}$ edition. Blackwell Publisher, Oxford.

Koulish, S.; Kramer, C. R. and Grier, H. J. (2002). Organization of the male gonad in a protogynous fish, Thalassoma bifasciatum (Teleostei: Labridae). J. Morphol., 254: 292-311.

Lahnsteiner, F. and Patzner, R. A. (1995). Fine structure of spermatozoa of two marine teleost fishes, the red mullet, Mullus barbatus (Mullidae) and the white sea bream, Diplodus sargus (Sparidae). J. Submicrosc. Cytol. Pathol., 27: 259-266.

Lee, T. H.; Chiang, T. H.; Huang, B. M.; Wang, T. C. and Yang, H. Y. (2006). Ultrastructure of spermatogenesis of the paradise fish, Macropodus opercularis. Taiwania, 51(3): 170-180.

Loir, M.; Cauty, C.; Planguetle, P. and Le Bail, P. Y. (1989). Comparative study of the male reproductive tract in seven families of South-American catfishes. Aquat. Living Resour., 2: 45-46.

Lone, K. P.; AL-Ablani, S. and Almatar, S. (2008). Spermatogenesis, maturation, seasonal variations and spawning season of silver pomfret (Pampus argenteus, Euphrasen) collected from the natural spawning grounds off the shore of Kuwait. Pakistan. J. Zool., 40(4): 263-273.

Magalhaes, A. L. B.; Andrade, R. F.; Gomes, B. V. C.; Perini, V. R.; Rizzo, E. and Bazzoli, N. (2011). Ultrastructure of the semicystic spermatogenesis in the South American freshwater characid Hemigrammus marginatus (Teleostei, Characiformes). J. Appl. Ichthyol., 27: 1041-1046.

Maricchiolo, G.; Genovese, L.; Laurà, R.; Micale, V. and Muglia, U. (2004). Fine structure of spermatozoa in the common pandora (Pagellus erythrinus Linnaeus, 1758) (Perciformes, Sparidae). Histol. Histopathol., 19: 1237-1240.

Maricchiolo, G.; Genovese, L.; Laurà, R.; Micale, V. and Muglia, U. (2007). Fine structure of spermatozoa in the gilthead sea bream (Sparus aurata Linnaeus, 1758) (Perciformes, Sparidae). Histol. Histopathol., 22: 79-83.

Maricchiolo, G.; Laurà, R.; Genovese, L.; Guerrera, M. C.; Micale, V. and Muglia, U. (2010). Fine structure of spermatozoa in the blackspot sea bream Pagellus bogaraveo (Brunnich, 1768) with some considerations about the centriolar complex. Tiss. Cell, 42: 88-96.

Mattei, X.; Siau, Y.; Thiaw, O. T. and Thiam, D. (1993). Peculiarities in the organizartion of testis of Ophidion sp. (Pisces, Teleostei): Evidence for two types of spermatogenesis in teleost fish. J. Fish Biol., 43:931-937.

Medina, A.; Megina, C.; Abascal, F. J. and Calzada, A. (2000). The spermatozoon morphology of Solea senegalensis (Kaup, 1858) (Teleostei, Pleuronectiformes). J. Submicrosc. Cytol. Pathol., 32: 645-650. 
Munoz, M.; Casadevall, M. and Bonet, S. (2002). Testicular structure and semicystic spermatogenesis in a specialized ovuliparous species: Scorpaena notata (Pisces, Scorpaenidae). Acta Zool., 83:213-219.

Nelson, J. S. (2006). Fishes of the World. $4^{\text {th }}$ edition. John Wiley and Sons, Inc., Hoboken, New Jersey, U.S.A.

Parenti, L. R. and Grier, H. J. (2004). Evolution and phylogeny of gonad, morphology in Bony Fishes. Integr. Comp. Biol., 44: 333-348.

Rahemo, Z. I. F. and Al-Shatter, N. M. S. (2012). Observations on reproductive organs and tissues of two freshwater cyprinid fishes, Barbus luteus and Varicorhinus trutta. J. Med. Sci., 3(12): 764-773.

Ramadan, A. A.; Ezzat, A. A.; Khadre, S. E. M.; Meguid, N. A. and El-Aziz, S. H. (1987a). Spermatogenesis in the marine hermaphrodite teleost fish, Sparus aurata. Folia Morphol., 35(2): 154-160.

Ramadan, A. A.; Ezzat, A. A.; Khadre, S. E. M.; Meguid, N. A. and El-Aziz, S. H. (1987b). Seasonal changes in the testis of the marine teleost fish, Sparus aurata. Folia Morphol., 35(2): 161-169.

Reynolds, E. S. (1963). The use of lead citrate at high $\mathrm{pH}$ as an electron opaque stain in electron microscopy. J. Cell Biol., 17: 208-212.

Ricardo, M. C. P., Aguiar, C. A.; Rizzo, E. and Bazzoli, N. (1996). Morfologia da micrópila e da célula micropilar em teleósteos neotropicais de água doce. Arq. Bras. Med. Vet. Zootec., 48(1): 17-24.

Romagosa, E.; Narahara, M. Y.; Borella, M. I.; Parreira, S. F. and Verani, N. F. (1999). Ultrastructure of the germ cells in the testis of matrinx, Brycon cephalus (Teleostei, Characidae). Tiss. Cell, 31(6): 540-544.

Sabat, M.; Lo Nostro, F.; Casadevall, M. and Munoz, M. (2009). A light and electron microscopic study on the organization of the testis and the semicystic spermatogenesis of the Genus Scorpaena (Teleostei, Scorpaenidae). J. Morphol., 270:662-672.

Salem, S. A. and Mohammed, S. Z. (1982). Studies on Mugil seheli and Mugil capito in Lake Timsah. I. Age and growth. Bull. Inst. Oceanog. Fish. A.R.E., 8 (1): 29-48.

Santos, R. N.; Andrade, C. C.; Santos, L. N. and Santos, A. F. (2006). Testicular maturation of Oligosarcus hepsetus (Cuvier) (Actinopterygii : Characidae) in a Brazilian tropical reservoir. Braz. J. Biol., 66: 1-10.

Schulz, R. W.; Franca, L. R.; Lareyre, J. J. Le Gac, F.; Chiarini-Garcia, H.; Nobrega, R. H. and Miura, T. (2010). Spermatogenesis in fish. Gen. Comp. Endocrinol., 165: 390-441.

Shahin, A. A. B. (2006). Spermatogenesis and spermatozoon ultrastructure in the Nile pebblyfish, Alestes dentex (Teleostei: Characiformes: Alestidae) in Egypt. J. Zool., 1(1): 1-16.

Siqueira-Silva, D. H.; Vicentini, C. A.; Ninhaus-Silveira, A. and Verissimo-Silveira, R. (2013). Reproductive cycle of the Neotropical cichlid yellow peacock bass Cichla kelberi: A novel pattern of testicular development. Neotrop. Ichthyol., 11(3):587596.

Spadella, M. A.; Oliveira, C. and Quagio-Grassiotto, I. (2006). Spermiogenesis and introsperm ultrastructure of Scoloplax distolothrix (Ostariophysi: Siluriformes: Scoloplacidae). Acta Zool. (Stockholm), 87: 341-348.

Sprando, R. L. and Russell, L. D. (1988). Spermiogenesis in bluegill (Lepomis macrochirus): a study of cytoplasmic events including cell volume changes and cytoplasmic elimination. J. Morphol., 198: 165-177.

Vergilio, C. S.; Moreira, R. V.; Carvalho, C. E. V. and Melo, E. J. T. (2013). Characterization of mature testis and sperm morphology of Gymnotus 
carapo (Gymnotidae, Teleostei) from the southeast of Brazil. Acta Zool. (Stockholm), 94(3): 364-370.

Vicentini, C. A.; Muñoz, M. E. and Vicentini, I. B. F. (2010). Ultrastructural aspects of spermatogenesis in Phalloceros caudimaculatus (Teleostei, Poeciliidae). Int. J. Morphol., 28(3): $951-956$.

Yoshino, T. and Seno, H. (1984). Mugilidae. In: "The Fishes of the Japanese Archipelago." Masuda, H., Amaola, K., Arage, C., Ueno T. and Yoshino T. (eds.). Tokaidaigaku-Shuppan, Tokyo.

Zaki, M. I.; Negm, R. K.; El-agamy, A. and Awad, G. S. (2005). Ultrastructure of male germ cells and character of spermatozoa in Boops boops (Family Sparidae) in Alexandria coast, Egypt. Egyp. J. Aquat. Res., 31(2): 293-313.

Zupa, R.; Fauvel, C.; Mylonas, C. C.; Santamaria, N.; Valentini, L.; Pousis, C. ; Papadaki, M. ; Suquet, M. ; de la Gandara, F.; Bello, G.; De Metrio G. and Corriero A. (2013). Comparative analysis of male germ cell proliferation and apoptosis in wild and captive Atlantic bluefin tuna, Thunnus thynnus L. J. Appl. Ichthyol., 29 (1): 71-81.

\section{EXPLANATION OF FIGURES}

Fig. 2: photographs of dissected adult males L. carinata, showing the morphological features of the testes during the different reproductive seasons; A: pre-spawning, $\mathrm{B}$ : spawning and $\mathrm{C}$ : post-spawning seasons.

Fig. 3: Photomicrograph of a T.S. of the testis of $L$. carinata in the spawning season, showing the seminiferous lobules, interlobular connective tissue septa, cysts and tunica albuginea. (HX \& E stain)

Fig. 4: Photomicrograph of a T.S. of the testis of L. carinata in the late post-spawning season, showing the seminiferous lobules, interlobular connective tissue septa, spermatogonium A, spermatogonia B, residual spermatozoa and tunica albuginea. (HX\& E stain)

Fig. 5: Photomicrograph of a T.S. of the testis of L. carinata in the late post-spawning season, showing the seminiferous lobules, interlobular connective tissue septa, cyst, spermatogonium A, spermatogonia B, Sertoli cells and interstitial cells. (HX \& E stain)

Fig. 6: Photomicrograph of a T.S. of the testis of $L$. carinata in the pre-spawning season, showing the seminiferous lobule, cysts, interlobular connective tissue septa, primary spermatocytes, secondary spermatocytes, spermatids, spermatozoa, spermatozoon head and tail. (HX\& E stain)

Fig. 7: Photomicrograph of a T.S. of the testis of $L$. carinata in the spawning season, showing the seminiferous lobules, interlobular connective tissue septa, cysts, spermatogonium A, primary spermatocytes, secondary spermatocytes, spermatozoa, spermatozoon head and tail. (Toluidine blue stain)

Fig. 8: Electron micrograph of the spermatogonium A of L. carinata, showing the nucleus, nucleolus, nuclear membrane, perinuclear nuages, cytoskeletal microtubule, ribosomes and mitochondria.

Fig. 9: Electron micrograph of the spermatogonium B of L. carinata, showing the nucleus, nucleolus, perinuclear nuage, ribosomes, mitochondria, intermitochondrial cement and endoplasmic reticulum.

Fig. 10: Photomicrograph of a T.S. of the testis of L. carinata in the pre-spawning season, showing the primary and secondary spermatocytes. (HX \& E stain)

Fig. 11: Electron micrograph of the primary spermatocytes of L. carinata, showing the nuclei, chromatin patches and nuclear membrane. 
Fig. 12: Electron micrograph of the primary spermatocyte of $L$. carinata, showing the nucleus, chromatin patches, nuclear membrane, intermitochondrial cement, ribosomes, mitochondria and endoplasmic reticulum.

Fig. 13: Electron micrograph of the secondary spermatocytes of L. carinata.

Fig. 14: Electron micrograph of the secondary spermatocyte of L. carinata, showing the nucleus, chromatin patches, mitochondria, intermitochondrial cement, ribosomes and endoplasmic reticulum.

Fig. 15: Photomicrograph of a T.S. of the testis of $L$. carinata in the pre-spawning season, showing the cysts, spermatids, spermatozoa and spermatozoa heads. (HX\& E stain)

Fig. 16: Electron micrograph of the early spermatids of $L$. carinata, showing the nuclei, cytoplasmic bridges, centrioles, mitochondria and endoplasmic reticulum.

Fig. 17: Electron micrograph of the middle spermatids of $L$. carinata, showing the nuclei, chromatin patches, centrioles and mitochondria.

Fig. 18: Electron micrograph of the middle spermatid of L. carinata, showing the nucleus, chromatin patches, nuclear fossa, the proximal and distal centrioles.

Fig. 19: Electron micrograph of the middle spermatids of $L$. carinata, showing the nucleus, nuclear fossa, centrioles and residual bodies.

Fig. 20: Electron micrograph of the late spermatids of L. carinata, showing the nucleus, chromatin patches, flagellum, cell membrane, cytoplasmic canal, and mitochondria.

Fig. 21: Photomicrograph of a T.S. of the testis of L. carinata in the spawning season, showing the seminiferous lobules, spermatozoa, spermatic duct and the sperm clouds. (HX\& E stain)

Fig. 22: Electron micrograph of the mature spermatozoon of L. carinata, showing the spermatozoon head, nucleus, chromatin patches, middle piece, flagellum and mitochondria.

Fig. 23: Electron micrograph of the flagella of the mature spermatozoa of L. carinata, showing the flagellar wings. The inserted part shows the microtubules of the flagellum.

\section{LIST OF ABBREVIATIONS}

$\begin{array}{ll}\text { Cen } & \text { Centriole. } \\ \text { Ch.pat } & \text { Chromatin patches. } \\ \text { Ct } & \text { Cysts. } \\ \text { Cy.brd } & \text { Cytoplasmic bridge. } \\ \text { Cyk.mit } & \text { Cytoskeletal microtubules. } \\ \text { Dis.cen } & \text { Distal centriole. } \\ \text { En.r } & \text { Endoplasmic reticulum. } \\ \text { Er.sd } & \text { Early spermatids. } \\ \text { Fl } & \text { Flagellum. } \\ \text { Fl.mm } & \text { Flagellum membrane. } \\ \text { Fl.win } & \text { Flagellar wing. } \\ \text { G.ap } & \text { Golgi apparatus. } \\ \text { Im.cm } & \text { Intermitochondrial cement. } \\ \text { In.ce } & \text { Interstitial cell. } \\ \text { Inl.c.t.s } & \text { Interlobular connective tissue septa. } \\ \text { La.sd } & \text { Late spermatids. } \\ \text { M } & \text { Mitochondria. } \\ \text { Md.pic } & \text { Middle piece. } \\ \text { Md.sd } & \text { Middle spermatids. }\end{array}$


Mit

$\mathrm{N}$

N.fo

N.mm

P.sc

Pe.n.ng

Po.cen

Res.bd

Res.sz

$\mathrm{Ri}$

$\mathrm{Sd}$

Se.lb

Sg.A

Sg.B

So.sc

Spr.cd

Spr.d

Sr.ce

$\mathrm{Sz}$

Sz.hd

Sz.ti

Ts

Tu.al
Microtubule.

Nucleus.

Nuclear fossa.

Nuclear membrane.

Primary spermatocytes.

Perinuclear nuage.

Proximal centriole.

Residual body.

Residual spermatozoa.

Ribosomes.

Spermatids.

Seminiferous lobules.

Spermatogonia A.

Spermatogonia B.

Secondary spermatocytes.

Sperm cloud.

Spermatic duct.

Sertoli cells.

Spermatozoa.

Spermatozoon head.

Spermatozoon tail.

Testes.

Tunica albuginea. 

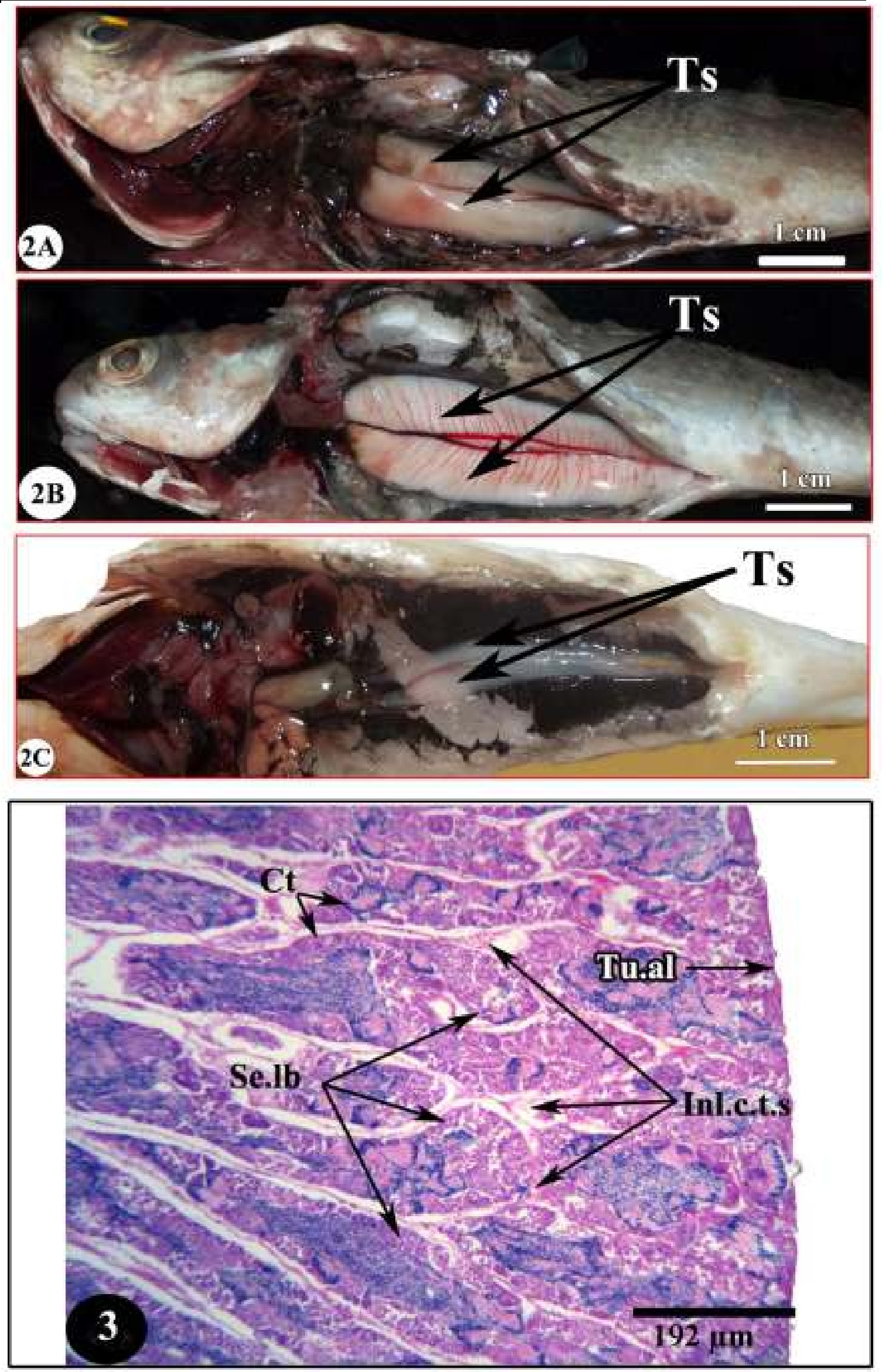

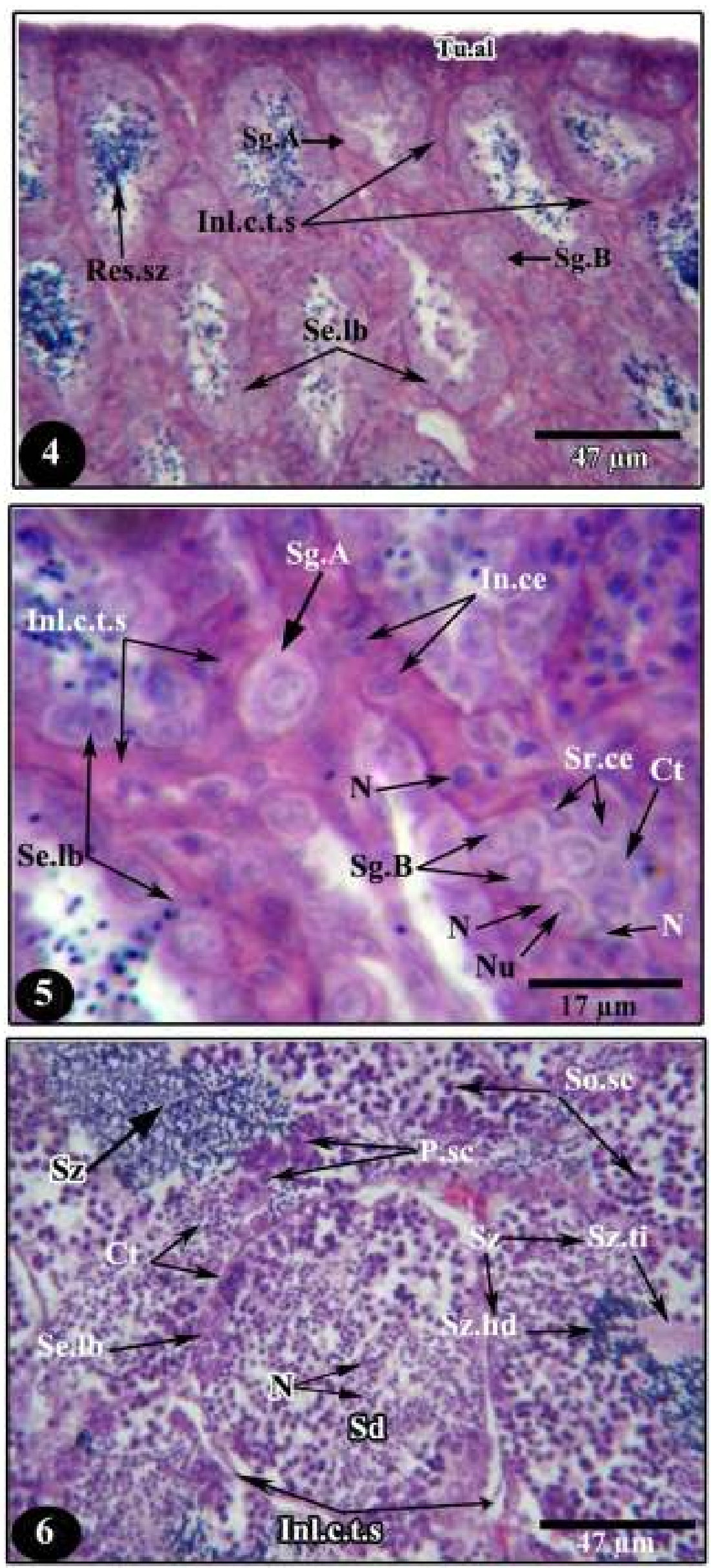

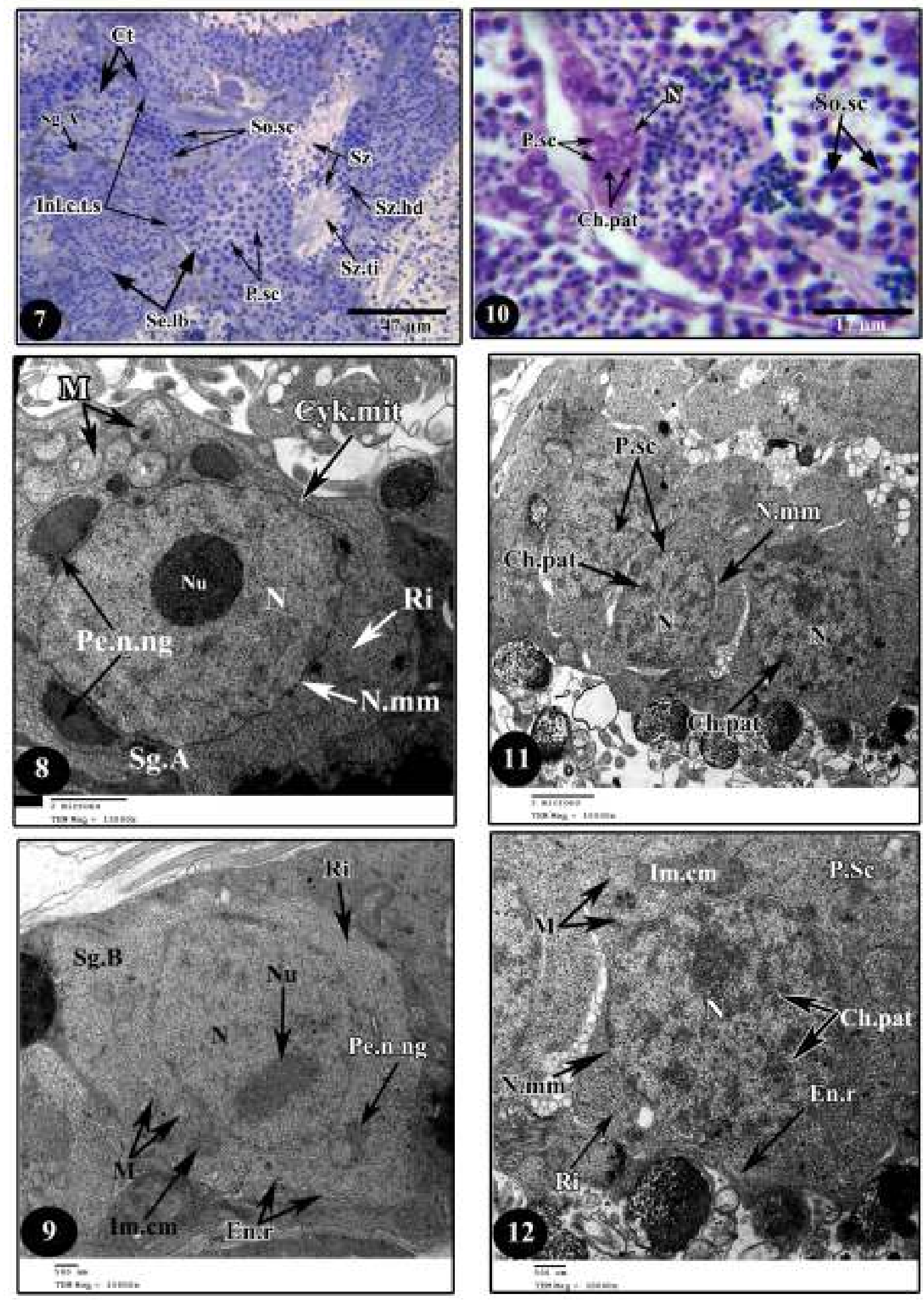

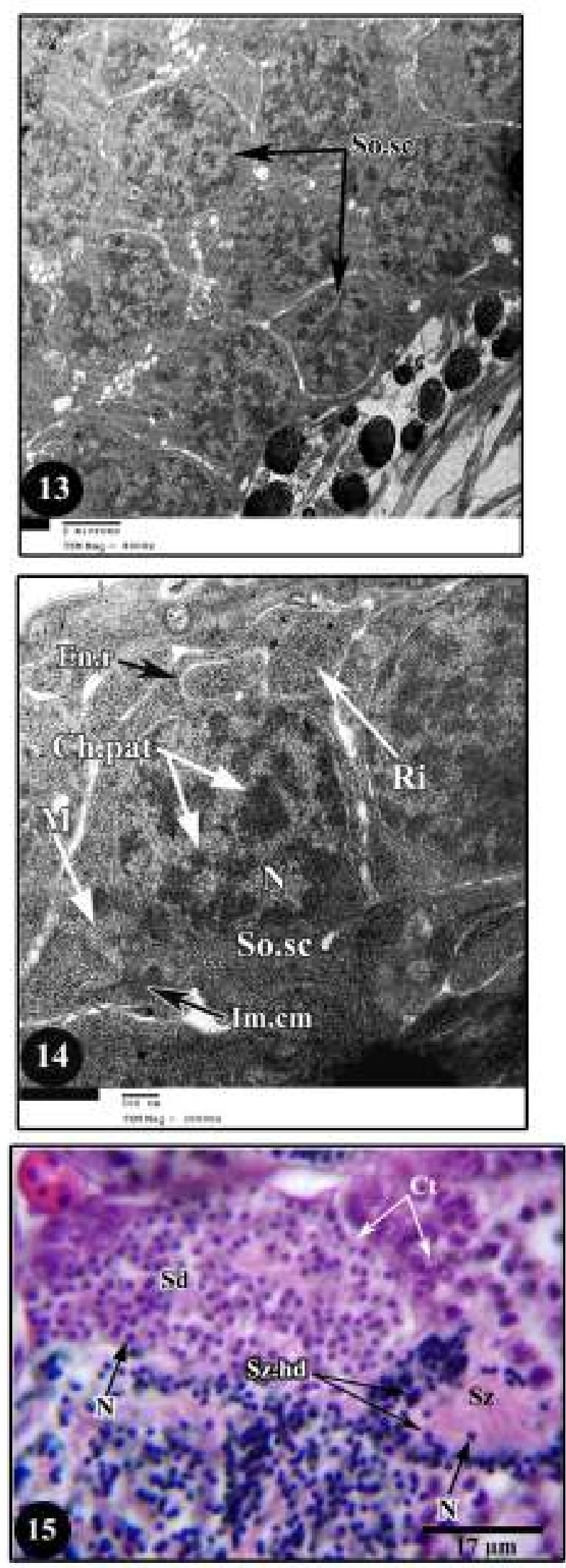
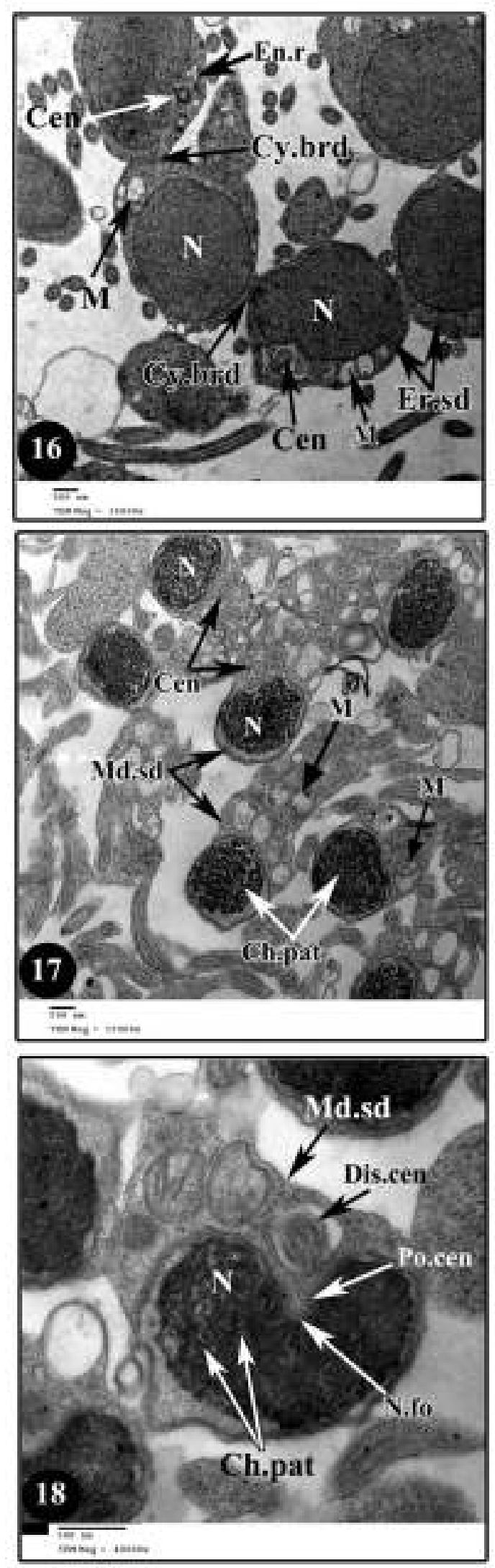

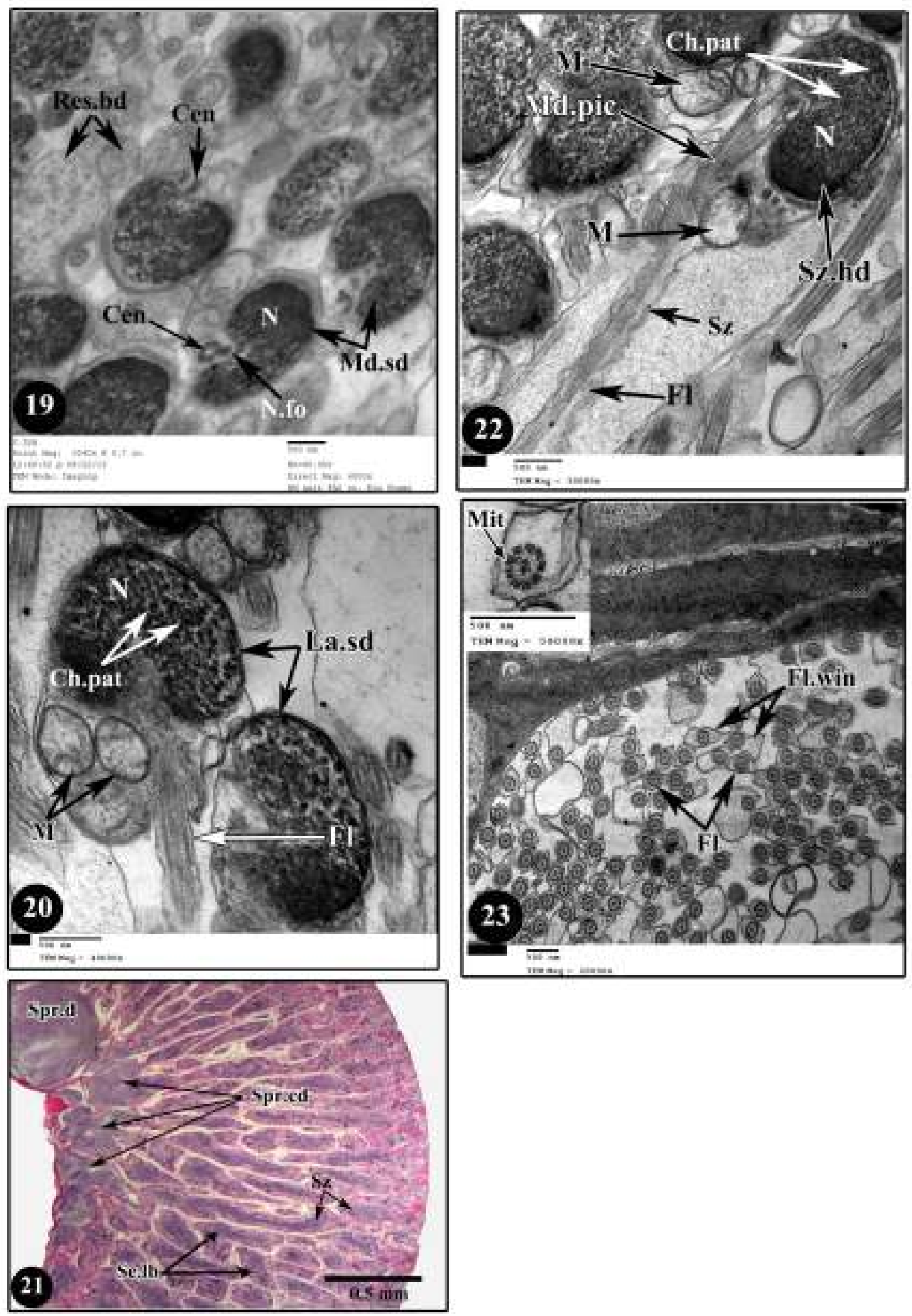


\section{ARABIC SUMMARY}

\section{دراسات مورفولوجية ونسيجية وتركيبية دقيقة على الخصى أسماك السهلية من خليج السويس و ارتباطها بدورتها التناسلية التصلية}

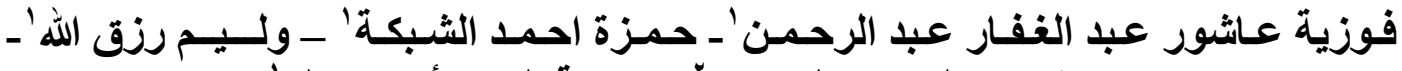

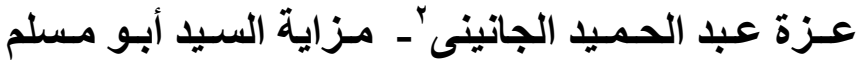

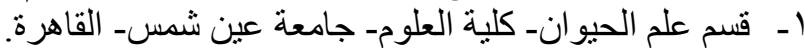

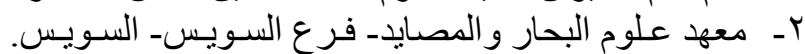

تعتبر أسماك السهلية (ليزا كاريناتا) من أسماك العائلة البورية ذات الأهمية الاقتصادية، ولذللك كانت دراسة إلتا

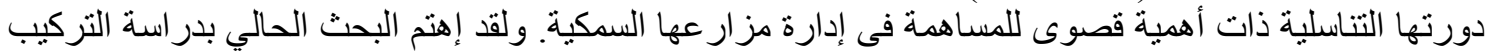

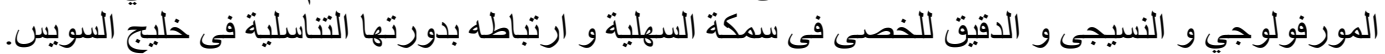

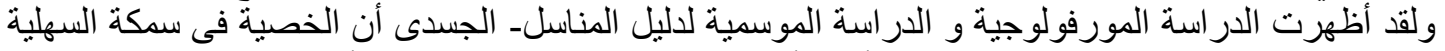

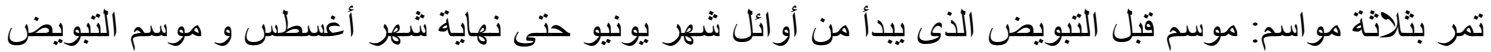

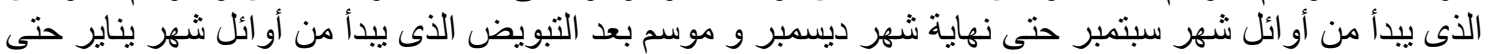

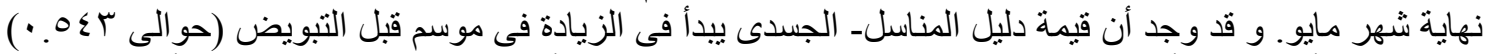

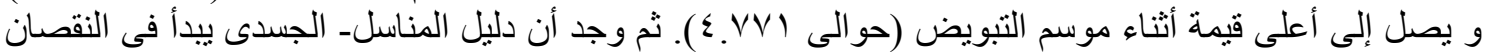

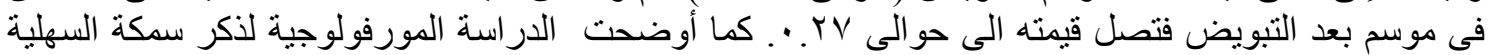

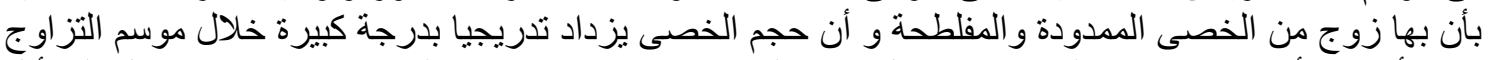

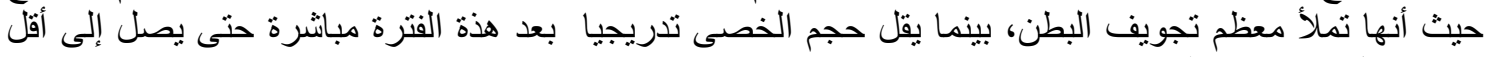

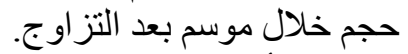

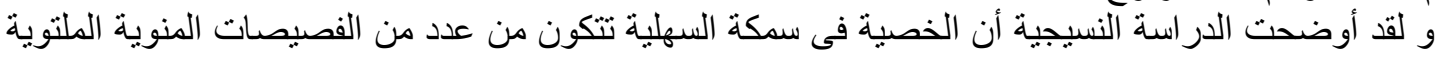

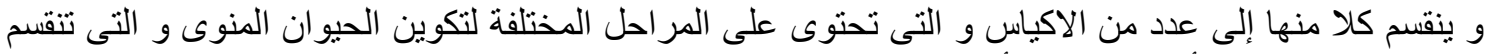

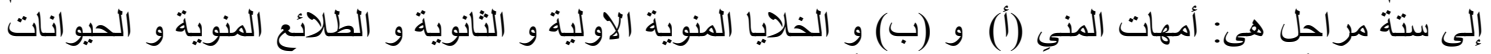

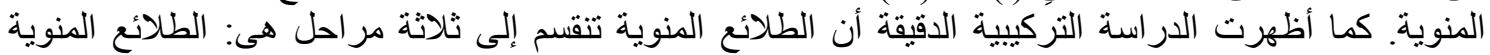

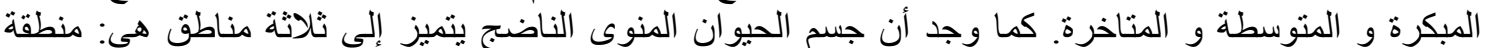
الر أس و المنطقة الوسطى و منطقة السوط أو الذيل. 